\title{
Encapsulation of Contaminated Soil in Concrete Mortar
}

\author{
Sreedevi Dawadi
}

M. R. Hansen

Bruce W. Berdanier

Fairfield University, bberdanier@fairfield.edu

Follow this and additional works at: https://digitalcommons.fairfield.edu/engineering-facultypubs

Copyright 2004 American Concrete Institute

Archived with permission from the copyright holder.

\section{Peer Reviewed}

\section{Repository Citation}

Dawadi, Sreedevi; Hansen, M. R.; and Berdanier, Bruce W., "Encapsulation of Contaminated Soil in Concrete Mortar" (2004). Engineering Faculty Publications. 32.

https://digitalcommons.fairfield.edu/engineering-facultypubs/32

\section{Published Citation}

Dawadi, Sreedevi, M. R. Hansen, and Bruce W. Berdanier. "Encapsulation of Contaminated Soil in Concrete Mortar." ACI Materials Journal 101, no. 5 (2004).

This item has been accepted for inclusion in DigitalCommons@Fairfield by an authorized administrator of DigitalCommons@Fairfield. It is brought to you by DigitalCommons@Fairfield with permission from the rightsholder(s) and is protected by copyright and/or related rights. You are free to use this item in any way that is permitted by the copyright and related rights legislation that applies to your use. For other uses, you need to obtain permission from the rights-holder(s) directly, unless additional rights are indicated by a Creative Commons license in the record and/or on the work itself. For more information, please contact digitalcommons@fairfield.edu. 


\title{
Encapsulation of Contaminated Soil in Concrete Mortar
}

\author{
by Sreedevi Dawadi, M. R. Hansen, and Bruce W. Berdanier
}

\begin{abstract}
A mixture of arsenic-contaminated soil and mortar was developed to study the effect of arsenic-contaminated soil on the strength of mortar and the effectiveness of the mortar in containing the arsenic. Preliminary laboratory analyses were conducted with spiked soil samples to verify percent recovery of the toxicity characteristic leaching procedure (TCLP). Five parameters were chosen for variation during the investigation: amount of contaminated soil (as a weight percentage of sand content), concentration of arsenic in the contaminated soil, water-cement ratio (w/c), amount of fly ash, and amount of silica fume. Compressive strength tests and TCLP tests were conducted on mortar samples. The test results showed that with the changes in the $\mathrm{w} / \mathrm{c}$, silica fume, and fly ash contents in the presence of arsenic, the compressive strength slightly increased from 7 to 28 to 90 days but did not show any major effect on the TCLP tests. The TCLP results were at the level (3 to $20 \mathrm{ppb}$ ) predicted to be established as the Drinking Water Equivalent Level (DWEL) by the United States Environmental Protection Agency (USEPA), indicating that mortar containing arsenic and contaminated soil may be a valid disposal solution.
\end{abstract}

Keywords: compressive strength; mortar; soil; water-cement ratio.

\section{INTRODUCTION}

Studies have been performed to investigate the technical feasibility, cost effectiveness, and implementation of stabilization/solidification (S/S) technology for the remediation of contaminated soils. Stabilization processes rely on additives that reduce the hazardous nature of a waste by converting the hazardous components of the waste into a form that minimizes the contaminant migration, reduces toxicity, or both. In contrast, solidification processes rely on the addition of reagents to a hazardous material, resulting in a solidified mass that typically has less compressibility and permeability. These processes have been successful in decreasing the potential for contaminant loss from a stabilized mass of materials including metals, volatiles, waste oils, and solvents. Disposing of the solidified/stabilized-contaminated soil in sanitary or secure landfills has been economical in the past, ${ }^{1}$ but landfill space in secure landfills is at a premium, and incineration processes are becoming cost prohibitive and socially unacceptable. Therefore, the incorporation of contaminated soils into usable structural concrete may be a valid disposal solution. Properly designed concrete could be used at contaminated sites to build the structures needed for parking lots, access roads, wash-down areas, control structures, and pads for retention ponds. ${ }^{1,2}$

The main objective of this project was to develop a mixture of contaminated soil and mortar (sand, cement, and water) with a low leaching potential through solidification and to evaluate the strength of the final monolith. The effects of contaminant level and contaminated soil proportion on the resultant strength were observed. The results of this preliminary study will be used to design a more intensive study to optimize the inclusion of the arsenic-contaminated soil in the mixture proportioning of structural concrete.
A homogenized soil sample was spiked with arsenic and mixed into mortar. The compressive strength and standard leaching potential were analyzed. A standard mortar mixture was incrementally modified by replacing the sand with contaminated soil. Standard cubes were made following the procedures of ASTM C $305^{3}$ by varying five parameters as follows: amount of contaminated soil, concentration of arsenic added to the soil as a contaminant, water-cement ratio $(w / c)$, amount of silica fume, and amount of fly ash. The compressive strength was determined according to ASTM C 109 at 7, 28, and 90 days. ${ }^{4}$ The TCLP tests were performed following the USEPA Standards ${ }^{5}$ and analyzed to determine the maximum contaminated soil and concentration of arsenic that adversely affects the strength of concrete mortar. Three samples for both compressive strength and TCLP were evaluated for each mixture at each time period. The results presented in the graphs in this paper for compressive strength and TCLP represent the mean values for each mixture at each time.

\section{Study of arsenic-contaminated soils}

Inorganic forms of arsenic are much more toxic than organic forms. ${ }^{6}$ The principal valence states of arsenic are $+3,+5$, and -3 . $^{7}$ Arsenical pesticides, natural geothermal sources, and mine tailings increase arsenic concentrations in soils. The adsorption of arsenicals in soil depends on soil $\mathrm{pH}$, texture, $\mathrm{Fe}, \mathrm{Al}$, and organic matter. The amount of arsenic adsorbed on soil increases as clay, $\mathrm{Fe}$, and $\mathrm{Al}$ content increases. Toxic amounts of arsenic in soils will limit the germination of seeds and reduce the viability of seedlings having a concentration that is greater than $10 \mathrm{ppm}$. Organic arsenic is used in catalysts, glass manufacturing, alloys, electronics, and weed killer. Inorganic forms of arsenic are used to kill insects or rodents, to preserve wood, and as a medicine for asthma and psoriasis. Arsenic levels in municipal sewage are variable from 1 to $18 \mathrm{ppm}$. An upper limit of $0.2 \mathrm{ppm}$ is recommended for arsenic in livestock drinking water and an upper limit of $0.05 \mathrm{ppm}$ for water intended for human consumption. In soils, the total arsenic concentration normally ranges from 1 to $40 \mathrm{ppm} .{ }^{8}$ Currently, United States Environmental Protection Agency (USEPA) is considering amendment to the safe drinking water act to set the Drinking Water Equivalent Level (DWEL) at $5 \mathrm{ppb}$.

\section{RESEARCH SIGNIFICANCE}

Arsenic contamination resulting from natural or xenobiotic sources in ground and surface waters is a major health concern for waters designated for agricultural or human

ACI Materials Journal, V. 101, No. 5, September-October 2004

MS No. 01-167 received June 5, 2001, and reviewed under Institute publication policies. Copyright (C) 2004, American Concrete Institute. All rights reserved, including the making of copies unless permission is obtained from the copyright proprietors. Pertinent discussion including authors' closure, if any, will be published in the July-August 2005 ACI Materials Journal if the discussion is received by April 1, 2005. 
$\overline{\text { Bruce W. Berdanier is an associate professor of civil engineering at Ohio Northern }}$ University, Ada, Ohio. He received his PhD from The Ohio State University Columbus, Ohio, in 1995. His research interests include surface water quality and in treatment processes for water and wastewater.

Sreedevi Dawadi is a post-doctoral research associate in the Department of Chemistry at Western Kentucky University, Bowling Green, Ky. She received her bachelor's degree in civil engineering from Osmania University, India, in 1999; her master's in civil engineering from the South Dakota School of Mines and Technology (SDSMT), Rapid City, S. Dak., in 2000; and her PhD from SDSMT in 2003.

M. R. Hansen, FACI, is a professor of civil engineering at SDSMT. He is a member of ACI Committees 116, Terminology and Notation; 120, History of Concrete; C 610, Field Technician Certification; E 802, Teaching Methods and Educational Materials; and E 803, Faculty Network Coordinating Committee, and is a member of the ACI Dakota Chapter His research interests include high-performance concrete and green concrete.

consumption uses. A great deal of time and money is being expended to conduct research and development of processes for removal of arsenic from such waters to concentrations as low as $5 \mathrm{ug} / \mathrm{L}$. This research project is significant in developing recommendations for encapsulation of arsenic-contaminated soils in concrete mortar while limiting leaching potential and maintaining sufficient strength. This study provides operational boundaries for the initiation of a more detailed study of arsenic encapsulation in structural concrete. Additionally, this study can also form the basis for development of a methodology for the concrete industry to use in the protection of ground and surface waters from contamination due to the leaching of arsenic from contaminated soils.

\section{Table 1-Proportions for soil samples}

\begin{tabular}{c|c|c|c}
\hline Mixture no. & Soil, $g$ & $\begin{array}{c}\text { Arsenic, } \\
\text { mg/kg of soil }\end{array}$ & Arsenic, g \\
\hline S1 & 25 & 0 & 0.000 \\
\hline S2 & 25 & 5 & 0.001 \\
\hline S3 & 25 & 50 & 0.005 \\
\hline S4 & 25 & 100 & 0.010 \\
\hline S5 & 25 & 200 & 0.021 \\
\hline S6 & 25 & 2000 & 0.208 \\
\hline & 25 & 20,000 & 2.083
\end{tabular}

\section{MATERIALS}

Commercially prepared topsoil was purchased for this study and dosed with the arsenic concentrations to have a consistent base material for addition of arsenic. Moisture content of the contaminated soil was determined using ASTM C $128 .{ }^{9}$

The cement used was Type I/II manufactured by GCC Dakota, Rapid City, S.D. Sand was commercial concrete sand obtained from a local concrete plant. Water was municipal tap water. Fly ash was Type F commonly used in the area. Silica fume was from Master Builders, Inc., and commonly used in the area.

\section{EXPERIMENTAL DESIGN}

Seven soil samples ( $\mathrm{S} 1$ to $\mathrm{S} 7$ ), as shown in Table 1, were prepared and TCLP tests were performed to evaluate the percent recovery obtained. This preliminary testing was an evaluation of the experimental methodology for mixing the soil and the arsenic, performing the TCLP, and the calibration of the inductively coupled plasma mass spectrometry (ICPMS) unit. Arsenic was added to the soil in the form of sodium arsenate as shown in the Appendix.

Twenty mixtures (A1 to A20), as shown in Table 2, were designed for the study by varying the five parameters as described previously. Five mortar mixtures (A1 to A5) varied the percent of contaminated soil $(0,5,10,15$ and $20 \%)$ to evaluate the adverse effects this range of percentages had on the compressive strength. Mixtures A6 to A10 maintained constant $10 \%$ contaminated soil and varied arsenic concentrations at $0,5,50,100,200 \mathrm{mg} / \mathrm{kg}$ of soil. Mixtures A11 to A20 held arsenic concentration constant at $50 \mathrm{mg} / \mathrm{kg}$ of soil, and contaminated soil was maintained at $10 \%$ of aggregate. The final ten mixtures were varied as follows: three mixtures (A11 to A13) with $w / c$ of $0.45,0.485$ and 0.52 ; three mixtures (A14 to A16) with fly ash of 0,20 , and $40 \%$ by weight of cement; and four mixtures (A17 to A20) with silica fume of $0,5,10$, and $15 \%$ by weight of cement were also prepared to determine their effect on mortar's

Table 2-Mortar proportions for $\mathbf{2 0}$ mixtures

\begin{tabular}{|c|c|c|c|c|c|c|c|c|c|c|c|}
\hline Mixture no. & Cement, $\mathrm{g}$ & Sand, g & $w / c$ & $\begin{array}{l}\text { Soil, \% of } \\
\text { aggregate }\end{array}$ & Soil, g & $\begin{array}{c}\text { Arsenic, } \\
\mathrm{mg} / \mathrm{kg} \text { of soil }\end{array}$ & Arsenic, $g$ & $\begin{array}{l}\text { Fly ash, \% } \\
\text { of cement }\end{array}$ & Fly ash, g & $\begin{array}{c}\text { Silica fume, } \% \\
\text { of cement }\end{array}$ & Silica fume, $\mathrm{g}$ \\
\hline $\mathrm{A} 1$ & 740 & 2035.0 & 0.485 & 0 & 0.0 & 0 & 0.0000 & 0 & 0.0 & 0 & 0 \\
\hline A2 & 740 & 1933.3 & 0.485 & 5 & 101.8 & 0 & 0.000 & 0 & 0.0 & 0 & 0 \\
\hline $\mathrm{A} 3$ & 740 & 1831.5 & 0.485 & 10 & 203.5 & 0 & 0.000 & 0 & 0.0 & 0 & 0 \\
\hline A4 & 740 & 1729.8 & 0.485 & 15 & 305.3 & 0 & 0.000 & 0 & 0.0 & 0 & 0 \\
\hline A5 & 740 & 1628.0 & 0.485 & 20 & 407.0 & 0 & 0.000 & 0 & 0.0 & 0 & 0 \\
\hline A6 & 740 & 1831.5 & 0.485 & 10 & 203.5 & 0 & 0.000 & 0 & 0.0 & 0 & 0 \\
\hline A7 & 740 & 1831.5 & 0.485 & 10 & 203.5 & 5 & 0.0042 & 0 & 0.0 & 0 & 0 \\
\hline A8 & 740 & 1831.5 & 0.485 & 10 & 203.5 & 50 & 0.0424 & 0 & 0.0 & 0 & 0 \\
\hline A9 & 740 & 1831.5 & 0.485 & 10 & 203.5 & 100 & 0.0848 & 0 & 0.0 & 0 & 0 \\
\hline A10 & 740 & 1831.5 & 0.485 & 10 & 203.5 & 200 & 0.1696 & 0 & 0.0 & 0 & 0 \\
\hline A11 & 740 & 1831.5 & 0.450 & 10 & 203.5 & 50 & 0.0424 & 0 & 0.0 & 0 & 0 \\
\hline A12 & 740 & 1831.5 & 0.485 & 10 & 203.5 & 50 & 0.0424 & 0 & 0.0 & 0 & 0 \\
\hline A13 & 740 & 1831.5 & 0.520 & 10 & 203.5 & 50 & 0.0424 & 0 & 0.0 & 0 & 0 \\
\hline A14 & 740 & 1831.5 & 0.485 & 10 & 203.5 & 50 & 0.0424 & 0 & 0.0 & 0 & 0 \\
\hline A15 & 592 & 1831.5 & 0.485 & 10 & 203.5 & 50 & 0.0424 & 20 & 148 & 0 & 0 \\
\hline A16 & 444 & 1831.5 & 0.485 & 10 & 203.5 & 50 & 0.0424 & 40 & 296 & 0 & 0 \\
\hline A17 & 740 & 1831.5 & 0.485 & 10 & 203.5 & 50 & 0.0424 & 0 & 0.0 & 0 & 0 \\
\hline A18 & 703 & 1831.5 & 0.485 & 10 & 203.5 & 50 & 0.0424 & 0 & 0.0 & 5 & 37 \\
\hline A19 & 666 & 1831.5 & 0.485 & 10 & 203.5 & 50 & 0.0424 & 0 & 0.0 & 10 & 74 \\
\hline A20 & 629 & 1831.5 & 0.485 & 10 & 203.5 & 50 & 0.0424 & 0 & 0.0 & 15 & 111 \\
\hline
\end{tabular}


strength and on TCLP results while still maintaining the arsenic-contaminated soil as an aggregate.

After completion of the initial twenty mixtures, five additional mixtures (M1 to M5) were made by keeping the amount of arsenic constant at $10,000 \mathrm{mg} / \mathrm{kg}$ of soil and varying the amount of soil by $0,10,20,30$, and $40 \%$ of sand and constant $w / c$ of 0.485 as shown in Table 3 . An arsenic concentration of $10,000 \mathrm{mg} / \mathrm{kg}$ would be characteristic of hazardous waste sludge or severely contaminated soil. This concentration is within the range of treatability claimed by some commercial solidification products. ${ }^{10,11}$ This procedure will provide an indication of a high upper bound for the use of arsenic-contaminated soil in cement mortar.

\section{Specimens}

Specimens of $2 \times 2 \times 2$ in. were made following the ASTM C 305-94 standard $^{3}$ and water-cured for 7, 28, and 90 days, respectively. The cubes were tested for compressive strength following the standard test method for compressive strength of mortars given by ASTM C 109. ${ }^{4}$ The TCLP test samples were prepared following the USEPA standards. ${ }^{5}$ Leached arsenic concentrations were measured on a inductively coupled mass spectrometer (ICPMS). The ICPMS was calibrated to detection limits of part per billion for arsenic in the TCLP leachate and has capabilities into the part-per-trillion range.

\section{TCLP results on soil samples}

\section{RESULTS AND DISCUSSION}

Arsenic concentrations of $0,5,50,100,200,2000$, and $20,000 \mathrm{mg} / \mathrm{kg}$ of soil in $25 \mathrm{mg}$ of soil were dosed for TCLP analysis. Figure 1 shows that the leaching of arsenic increased with the amount dosed. TCLP tests recovered close to $100 \%$ of the dosed concentration for all the soil samples.

\section{Compressive strength and TCLP results for $\mathbf{2 0}$ mixtures}

Effect of soil content-The compressive strengths for Mixtures A1 to A5 were determined and the mean values are shown in Table 4 after 7, 28, and 90 days of curing. From Fig. 2 it was observed that the strength appeared to decrease with the increase in the soil content. No TCLP tests were performed for these samples because they were not dosed with arsenic, and the purpose of Mixtures A1 to A5 is to settle on a level of contaminated soil to use in the remaining tests. Ten percent soil content was chosen for the remaining tests as sufficient for this initial analysis of a mortar that could be used in structural concrete mixtures. The 90-day compressive strength still had a mean value close to $5000 \mathrm{psi}$ (30 MPa).

Effect of arsenic content-Mixtures A6 to A10 contained a constant $10 \%$ soil and $w / c$ of 0.485 . Varying concentrations of arsenic dosed as follows: 0, 5, 50, 100, $200 \mathrm{mg} / \mathrm{kg}$ of soil. Figure 3 shows that there appears to be no particular trend in the effect of this range of arsenic concentrations on the observed compressive strength.

The 7-, 28-, and 90-day TCLP results in Fig. 4 showed that the amount of arsenic leaching out in all the mixture samples was consistent at low arsenic concentrations over time. The 28-day leached concentrations, however, were considerably higher at initial arsenic concentrations over $50 \mathrm{mg} / \mathrm{kg}$.

Effect of $\mathrm{w} / \mathrm{c}-$ Mixtures A11, A12, and A13 were made with $10 \%$ soil and arsenic of $50 \mathrm{mg} / \mathrm{kg}$ of soil constant and $w / c$ of $0.45,0.485$, and 0.52 , respectively. Figure 5 showed that at 7 and 28 days of testing, there was a gradual decrease

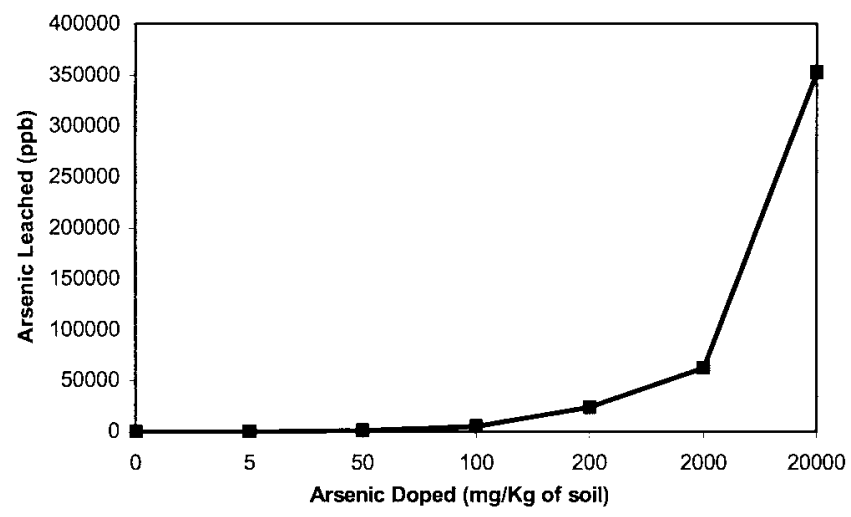

Fig. 1-TCLP results for arsenic content in soil samples.

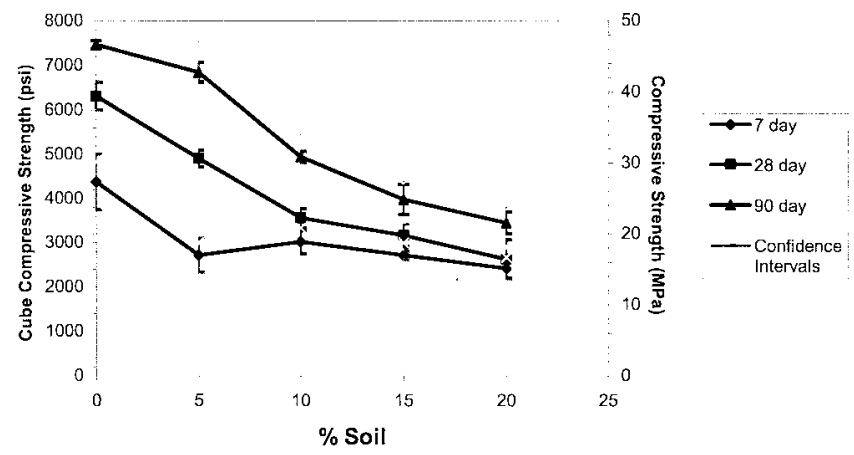

Fig. 2-Compressive strength as affected by soil cement.

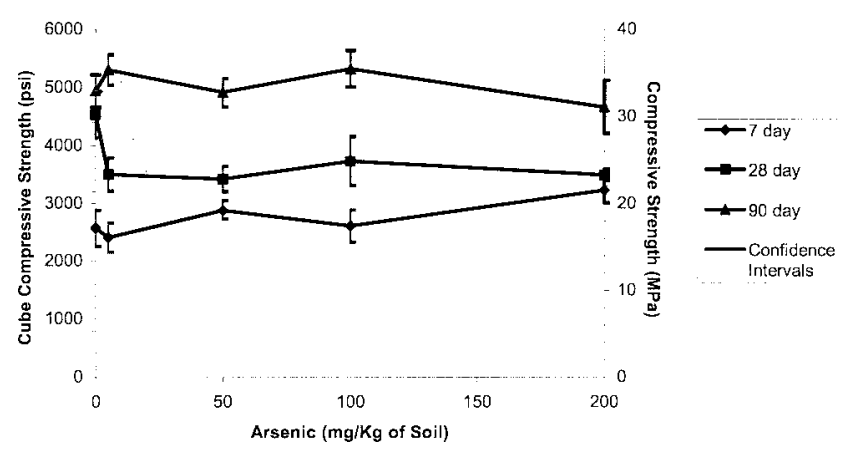

Fig. 3-Compressive strength as affected by arsenic content.

Table 3-Mortar proportions for final mixtures

\begin{tabular}{c|c|c|c|c|c|c|c|c|c}
\hline $\begin{array}{c}\text { Mix } \\
\text { ture } \\
\text { no. }\end{array}$ & $\begin{array}{c}\text { Cement, } \\
\mathrm{g}\end{array}$ & $\begin{array}{c}\text { Sand, } \\
\mathrm{g}\end{array}$ & $\begin{array}{c}\text { w/c } \\
\text { M1 }\end{array}$ & $\begin{array}{c}\text { Soil, } \\
\text { aggre of } \\
\text {-gates }\end{array}$ & $\begin{array}{c}\text { Soil, } \\
\mathrm{g}\end{array}$ & $\begin{array}{c}\text { Arsenic, } \\
\mathrm{mg} / \mathrm{kg} \\
\text { of soil }\end{array}$ & $\begin{array}{c}\text { Sodium } \\
\text { arsenate, } \\
\mathrm{g}\end{array}$ & $\begin{array}{c}\text { Fly } \\
\text { ash, } \\
\% \text { of } \\
\text { cement }\end{array}$ & $\begin{array}{c}\text { Silica } \\
\text { fume, } \\
\% \text { of } \\
\text { cement }\end{array}$ \\
\hline M2 & 740.0 & 1831.5 & 0.485 & 10 & 203.5 & 10,000 & 8.4792 & 0 & 0 \\
\hline M3 & 740.0 & 1628.0 & 0.485 & 20 & 407.0 & 10,000 & 16.9583 & 0 & 0 \\
\hline M4 & 740.0 & 1424.5 & 0.485 & 30 & 610.5 & 10,000 & 25.4375 & 0 & 0 \\
\hline M5 & 740.0 & 1221.0 & 0.485 & 40 & 814.0 & 10,000 & 33.9167 & 0 & 0 \\
\hline
\end{tabular}

in the compressive strength, which indicated that the $w / c$ of 0.45 was the best proportion to use for getting higher compressive strength.

The 7- and 90-day TCLP results in Fig. 6 showed that the amount of arsenic leaching out in all the three mixture samples appears to be approximately equal with no effect from the $w / c$. The 28-day TCLP results indicated higher levels of arsenic leaching on the order of two to four times the 7- and 90-day values. 


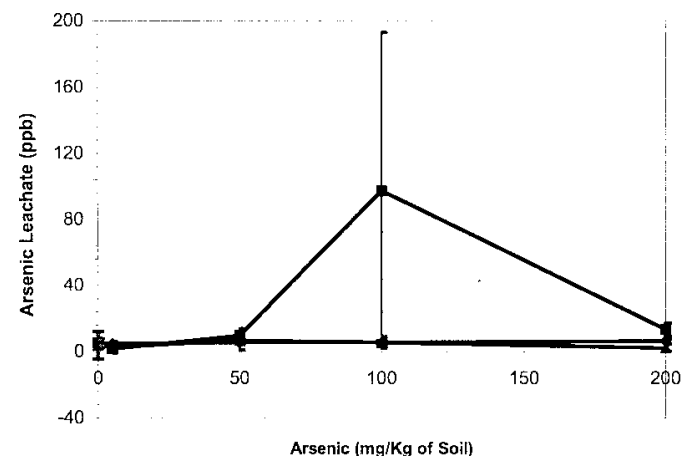

Fig. 4-TCLP as affected by arsenic content.

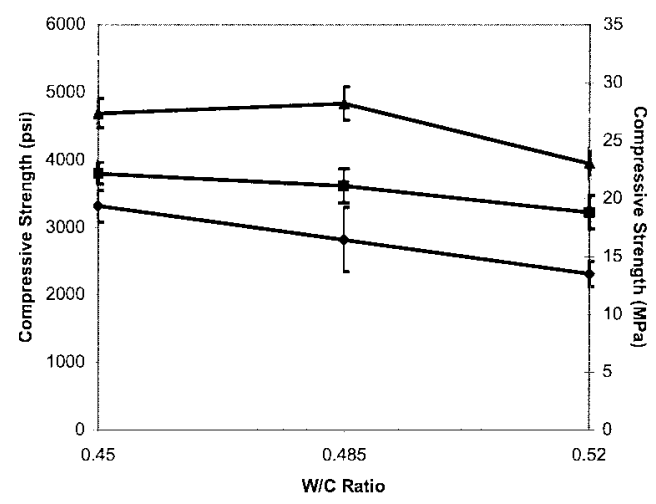

Fig. 5-Compressive strength as affected by w/c.

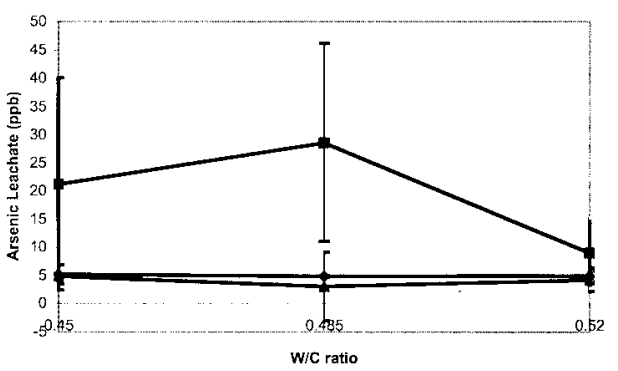

Fig. 6-TCLP as affected by w/c.

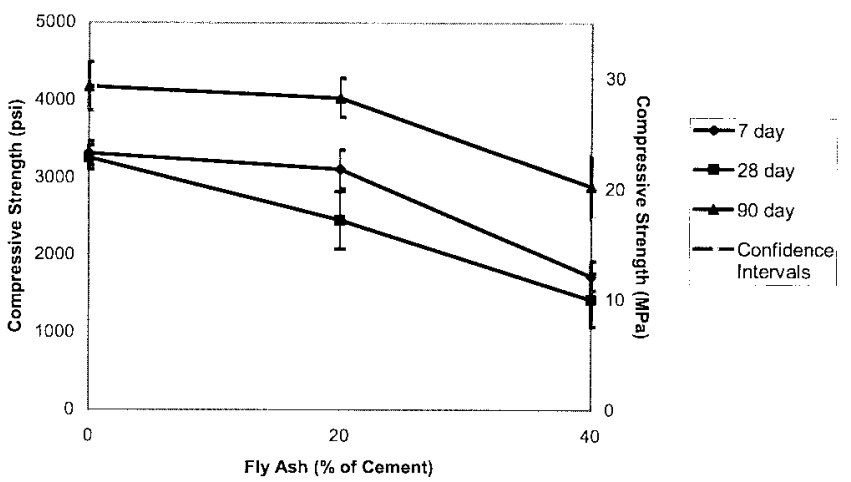

Fig. 7-Compressive strength as affected by fly ash content (initial mixture).

Effect of fly ash content-With fly ash as the variable, Mixtures A14, A15, and A16 were made with $10 \%$ of soil, arsenic of $50 \mathrm{mg} / \mathrm{kg}$ of soil, w/c of 0.485 constant, and fly ash of 0,20 , and $40 \%$ of cementitious material as shown in Table 2. Figure 7 showed that at 7 - and 28-day tests, there appears to be a gradual decrease in the compressive strength

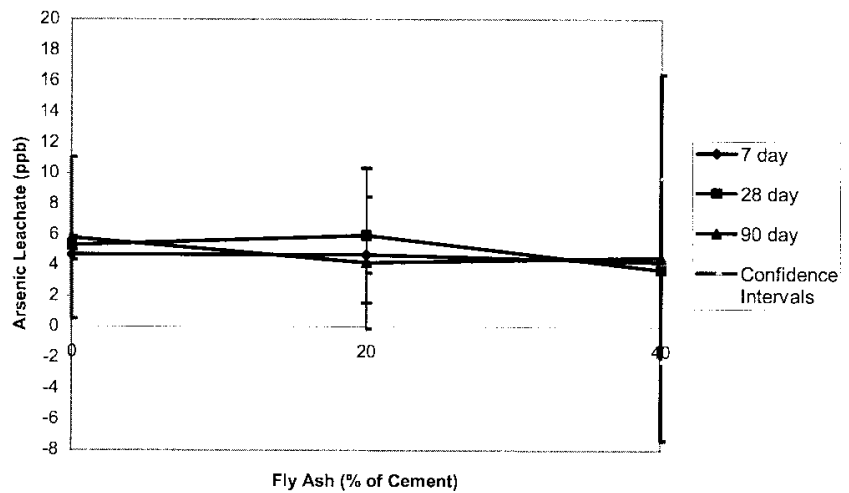

Fig. 8-TCLP as affected by fly ash content (initial mixture).

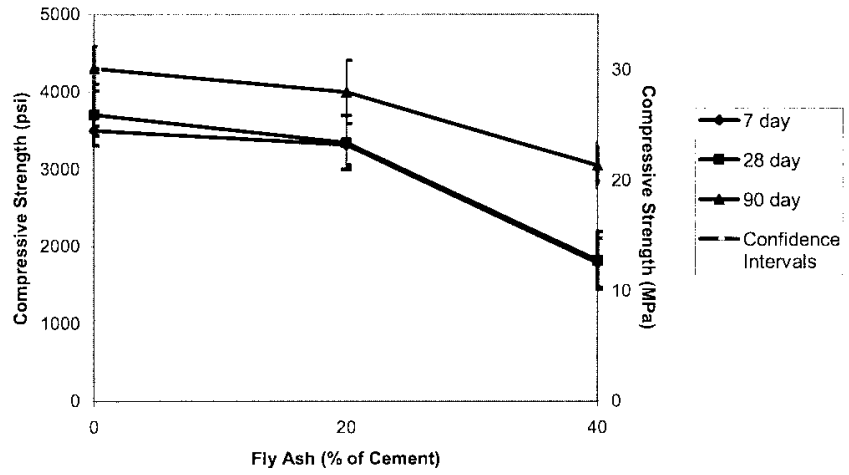

Fig. 9-Compressive strength as affected by fly ash content (repeated mixture).

Table 4-Compressive strength as affected by soil cement

\begin{tabular}{c|c|c|c|c|c|c|c}
\hline \multirow{2}{*}{$\begin{array}{c}\text { Mixture } \\
\text { no. }\end{array}$} & \% soil & \multicolumn{2}{|c|}{$\begin{array}{c}\text { 7-day } \\
\text { compressive } \\
\text { strength }\end{array}$} & \multicolumn{2}{c|}{$\begin{array}{c}\text { 28-day } \\
\text { compressive } \\
\text { strength }\end{array}$} & \multicolumn{2}{c}{$\begin{array}{c}\text { 90-day } \\
\text { compressive } \\
\text { strength }\end{array}$} \\
\cline { 3 - 8 } A1 & 0 & 4380 & 30.1 & 6320 & 43.5 & 7470 & 51.4 \\
\hline A2 & 5 & 2720 & 18.7 & 4910 & 33.8 & 6850 & 47.1 \\
\hline A3 & 10 & 3020 & 20.8 & 3560 & 24.5 & 4950 & 34.0 \\
\hline A4 & 15 & 2720 & 18.7 & 3170 & 21.8 & 3980 & 27.4 \\
\hline A5 & 20 & 2420 & 16.6 & 2630 & 18.1 & 3450 & 23.7 \\
\hline
\end{tabular}

with increasing fly ash content, but at 90 days, all strengths are higher, as is normal with mixtures containing fly ash.

The 7-day TCLP results for Mixtures A14, A15, and A16 in Fig. 8 showed that the amount of arsenic leaching out was approximately the same with increasing fly ash percentage and over time. The results are all within a $2 \mathrm{ppb}$ range.

Because the strength decreased from 7 to 28 days, three new mixtures with the same proportions were completed to verify the results. The results shown in Fig. 9 indicate that there was decreasing strength at 7 and 28 days, and the strength at 28 days of all the cubes was slightly higher than that at 7 days. The 90-day compressive strength results were all higher but decrease in strength with the increase in the fly ash content.

The 7- and 28-day TCLP results for the repeated mixtures indicated lower concentrations of arsenic in the leachate compared to the initial mixtures. The concentration of arsenic leachate appeared to consistently increase over the 90-day testing period for all the mixtures, as shown in Fig. 10. However, the results still appear to be around 5 ppb or less. The percent average retained was $97.2 \%$, which indicates that 


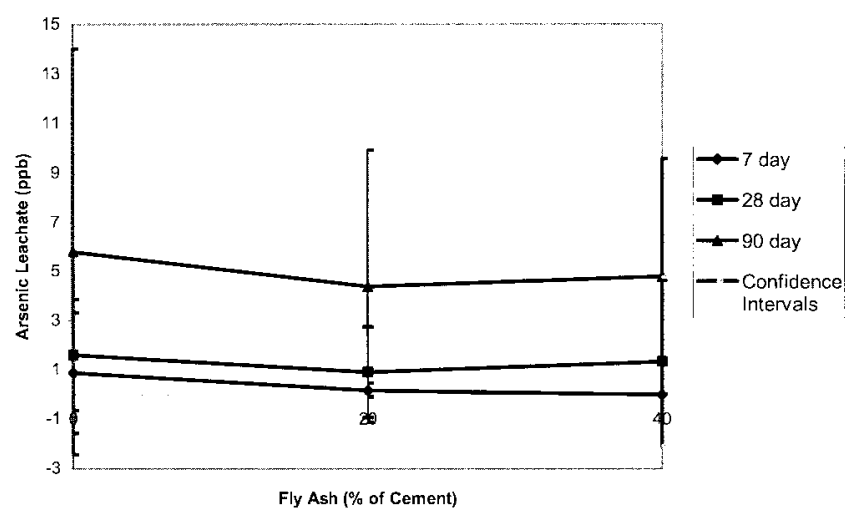

Fig. 10-TCLP as affected by fly ash content (repeated mixture).

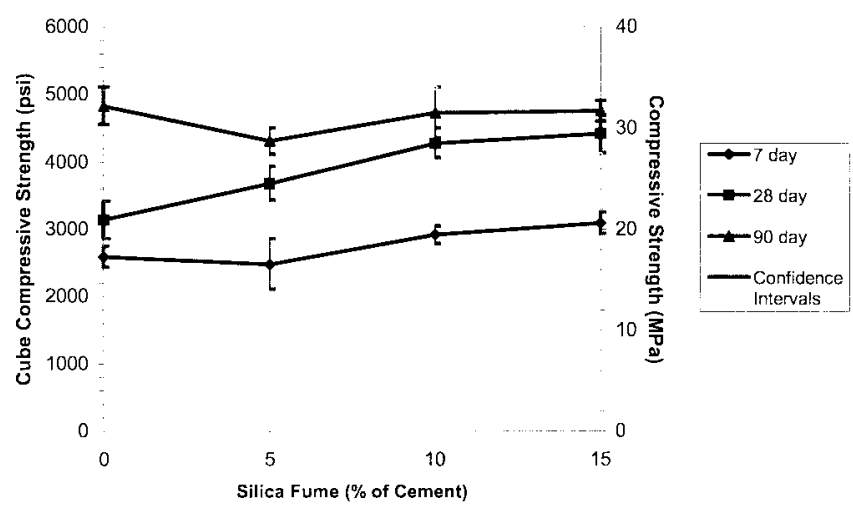

Fig. 11-Compressive strength as affected by silica fume content.

fly ash mortar is a good solidifying material in binding wastes. Further studies may be warranted to investigate the effects of fly ash on strength and arsenic leachate concentration at very low arsenic concentrations and low fly ash percentages.

Effect of silica fume content-Mixtures A17, A18, A19, and A20 were made with $10 \%$ soil, arsenic of $50 \mathrm{mg} / \mathrm{kg}$ of soil, $w / c$ of 0.485 and silica fume of 0,20 , and $40 \%$ of cementitious material as shown in Table 2.

The results in Fig. 11 indicate that 7- and 28-day strength slightly increased with percent silica fume. At 90-day tests, the strength decreased at $5 \%$ of silica fume and there was a gradual increase at 10 and $15 \%$ silica fume content. There is no significant strength benefit from silica fume.

The TCLP results did not indicate a consistent relationship between the presence of silica fume in the mortar mixture and arsenic concentration in the leachate as shown in Fig. 12. The resultant leachate concentrations were all at the $6 \mathrm{ppb}$ level or less.

\section{Compressive strength and TCLP results for final mixtures}

Mixtures M1 to M5 were made with arsenic of $10,000 \mathrm{mg} / \mathrm{kg}$ of soil; $0,10,20,30$, and $40 \%$ of aggregates; and $w / c$ of 0.485 as shown in Table 3.

The compressive strength tests and TCLP tests were performed to study the effect of very high concentration of arsenic and increasing proportions of soil content on mortar strength. Mixture M1 is the control mixture and has the highest compressive strength. Figure 13 indicates a decrease in the compressive strength for the mortar as soil content is increased up to $20 \%$. The 7- and 28-day compressive strengths for the last two mixtures containing 30 and $40 \%$ of soil could not be

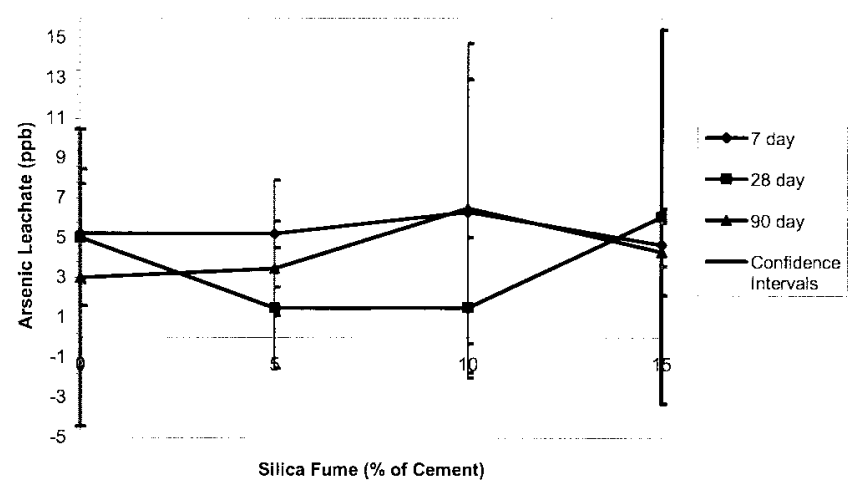

Fig. 12-TCLP as affected by silica fume content.

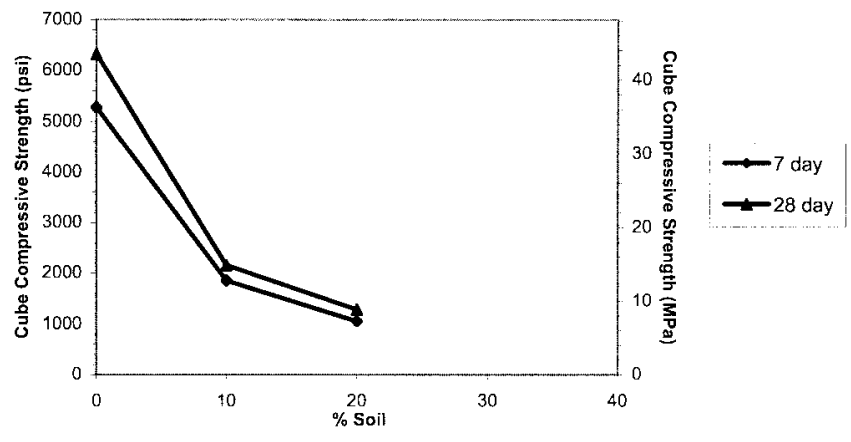

Fig. 13-Compressive strength as affected by soil cement.

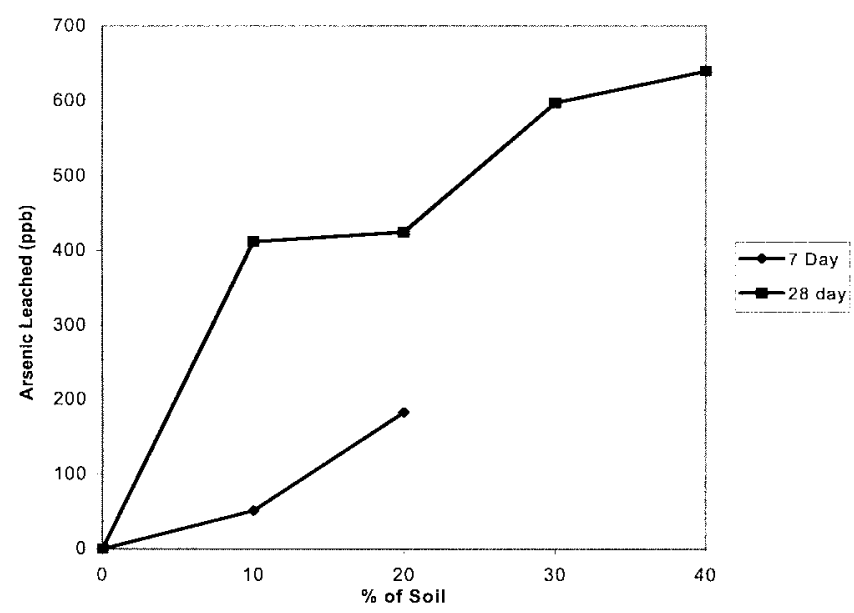

Fig. 14-TCLP results as affected by soil content.

obtained, as the setting time for these mixtures was more than 28 days.

From these results, it appears that the addition of higharsenic-concentration soils (on the order of $10,000 \mathrm{mg} / \mathrm{kg}$ ) beyond $10 \%$ soil to the mortar mixture would greatly reduce the final compressive strength for structural concrete.

Figure 14 shows the results of the TCLP tests for the higharsenic-concentration mixtures. As expected, the concentration of arsenic in the leachate increased with percentage of soil. The leachate concentrations are higher than would be accepted if the methodology were used for protection of groundwater. The 7-day TCLP tests were not performed on the last two mixtures, as their set time was more than 7 days. Figure 14 also indicates that the leaching potential increases with time, as the results for the TCLP at 28 days are considerably higher than those at 7 days. It should be noted that although the mortar did not retain the arsenic to the low ppb levels 
required for drinking water protection, the method still shows promise as the leached concentration is on the order of less than $1 \%$ of the initial dosage.

\section{STATISTICAL ANALYSIS}

Linear regression analysis was performed on all of the data for compressive strength and TCLP in relation to the varying of arsenic concentration, $w / c$, fly ash, and silica fume. Trends observed were found to have low slope values have low correlation coefficients.

Statistical analysis was performed on compressive strength results for mixtures (A1 to A20) and on TCLP results for mixtures (A6 to A20) to evaluate the statistical significance of the results in relation to curing time. Oneway analysis of variance (ANOVA) using statistical software was performed for each mixture. Resultant $p$ values were considered significant if they indicated that the hypothesis - that the means were equivalent — could be rejected at a level lower than 0.05 .

The experimental results showed that the compressive strength appeared to increase from 7 to 90 days for all of the mixtures. The resultant $p$ values from the ANOVA confirmed that the compressive strength increase is statistically significant from 7 to 90 days for all of the mixtures.

The TCLP test was performed for the mixtures (A6 to A20) containing arsenic. The ANOVA results showed that apparent increases in the TCLP concentrations from 7 to 28 days were significant for all of the mixtures except for the mixtures with varying percent fly ash and for the $15 \%$ silica fume mixture. Apparent decreases in TCLP concentrations from 7 to 28 days were significant only for the mixtures with arsenic at $5 \mathrm{mg} / \mathrm{kg}$ and with silica fume at $5 \%$. Apparent decreases in TCLP from 28 to 90 days were significant only in the mixtures with arsenic at 100 and $200 \mathrm{mg} / \mathrm{kg}$ and in the mixtures with $w / c$ at 0.45 and 0.485 . Apparent increases in TCLP from 28 to 90 days were significant in fly ash at $40 \%$, and in silica fume at 5 and $10 \%$.

\section{CONCLUSIONS AND RECOMMENDATIONS}

Based on the results of this study, the following conclusions can be made:

1. The strength of the mortar mixtures decreased with the increase in the soil content, fly ash percentage, and $w / c$;

2 . The concentration of arsenic in the leachate increased with time for the mixtures containing $10,000 \mathrm{mg}$ of arsenic/ $\mathrm{kg}$ of soil and soil content of 10, 20,30, and $40 \%$. The evaluated method reduced the leachate concentration to approximately $1 \%$ of the dosage concentration but would not meet currently proposed groundwater protection levels for this high of concentration;

3. Testing at 7, 28, and 90 days indicated that the TCLP concentration of arsenic in the leachate and the compressive strength was approximately the same for all dosage concentrations up to $200 \mathrm{mg}$ arsenic/kg soil; and

4. Testing of mortar encapsulation of arsenic-contaminated soil (up to $200 \mathrm{mg}$ arsenic/kg soil) indicates that the method was successful in reducing the arsenic concentration in leachate to approximately $5 \mathrm{ppb}$.

\section{Recommendations for future research}

Future research should be focused on studying the effects of arsenic-contaminated soil on structural concrete.
Additional investigation should be conducted into the interfacial chemistry reaction(s) that determine the ability of the mortar to encapsulate the arsenic-contaminated soil.

Future research should identify the concentration of arsenic contaminated soil in the 1000 to $10,000 \mathrm{mg}$ arsenic/kg soil range that can be successfully encapsulated to meet Environmental Protection Agency standards based on TCLP.

\section{REFERENCES}

1. Cullinane, M. J., Jr.; Jones, L. W.; and Malone, P. G., "Handbook of Stabilization/Solidification of Hazardous Wastes," EPA/540/2-86/001, 1986.

2. Conner, J. R., Chemical Fixation and Solidification of Hazardous Wastes, Van Nostrand Reinhold, Chemical Waste Management, Inc., 1990.

3. ASTM C 305-94, "Standard Practice for Mechanical Mixing of Hydraulic Cement Pastes and Mortars of Plastic Consistency," ASTM International, West Conshohocken, Pa., 1994, 3 pp.

4. ASTM C 109-93, "Standard Test Method for Compressive Strength of Hydraulic Cement Mortars," ASTM International, West Conshohocken, Pa., V. 04.02, 1993, 6 pp.

5. Jackman, A. P., and Powell, R. L., Hazardous Waste Treatment Technologies, Park Ridge, Nyes Publications, 1991.

6. "Arsenic in Drinking Water," Handbook of Ground Water and Drinking Water, USEPA, Washington, DC, 1999.

7. Environmental Protection Agency, Environmental Protection Agency Record, EPA ID\# MED980504393, York County, Saco, 1990.

8. Brown, K. W. et al., "Hazardous Waste Land Treatment," USEPA Municipal Environmental Research Laboratory, Cincinnati, Ohio, EPA/ 530/SW-874, 1980.

9. ASTM C 128-97, "Standard Test Methods for Specific Gravity and Absorption of Fine Aggregate," ASTM International, West Conshohocken, Pa., 1997, 6 pp.

10. Environmental Protection Agency, "Solidification/Stabilization Process," Technology Evaluation Report, SITE Program Demonstration Test, Soliditech, Inc., 1990.

11. Environmental Protection Agency, "Solidification/Stabilization Process," Office of Research and Development RREL, Chemfix Technologies, Inc., USEPA/540/A5-89/011, 1991.

\section{APPENDIX-CALCULATIONS TO DETERMINE AMOUNT OF ARSENIC REQUIRED}

The calculations used to determine the amount of arsenic required for dosing in the soil are explained as follows:

The compound taken was sodium arsenate, $\mathrm{Na}_{2} \mathrm{HAsO}_{4}$. $7 \mathrm{H}_{2} \mathrm{O}$. The atomic weight of $\mathrm{Na}_{2} \mathrm{HAsO}_{4} \cdot 7 \mathrm{H}_{2} \mathrm{O}$ is

$$
\begin{gathered}
=2(22.989)+1(1)+1(74.9216)+4(15.994) \\
+7[2(1)+15.994] \\
\frac{311.8946 \mathrm{~g}}{\text { mole }} \mathrm{Na}_{2} \mathrm{HAsO}_{4} \cdot 7 \mathrm{H}_{2} \mathrm{O}
\end{gathered}
$$

The amount of arsenic in $\mathrm{Na}_{2} \mathrm{HAsO}_{4} \cdot 7 \mathrm{H}_{2} \mathrm{O}$ is calculated as follows:

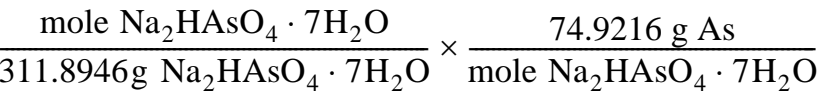

$$
\begin{aligned}
& \frac{100 \mathrm{mg} \mathrm{As}}{\mathrm{g} \mathrm{As}}=\frac{240 \mathrm{mg} \mathrm{As}}{\mathrm{g} \mathrm{Na}_{2} \mathrm{HAsO}_{4} \cdot 7 \mathrm{H}_{2} \mathrm{O}}
\end{aligned}
$$

Therefore, $1 \mathrm{mg} \mathrm{As} / \mathrm{kg}$ of soil =

$\frac{\mathrm{g} \mathrm{Na}_{2} \mathrm{HAsO}_{4} \cdot 7 \mathrm{H}_{2} \mathrm{O}}{\mathrm{g} \text { soil }} \times \frac{1000 \mathrm{~g} \text { soil }}{\mathrm{kg} \mathrm{soil}} \times \frac{240 \mathrm{mg} \mathrm{As}}{\mathrm{g} \mathrm{Na}_{2} \mathrm{HAsO}_{4} \cdot 7 \mathrm{H}_{2} \mathrm{O}}$ 